\title{
THE DALIAN PORT CLUSTER: SPATIAL PRACTICE OF THE ONE BELT ONE ROAD INITIATIVE
}

\author{
PENGLIN ZHU ${ }^{1} \&$ CAROLA HEIN ${ }^{2}$ \\ ${ }^{1}$ Chair of History of Architecture and Urban Planning, Delft University of Technology, The Netherlands \\ ${ }^{2}$ Chair of Architecture and Urban Planning, Delft University of Technology, The Netherlands
}

\begin{abstract}
The Chinese government is heavily investing in trade-related infrastructure with its One Belt One Road Initiative (OBOR), a proposal to build a New Silk Road or network of trade routes. This infrastructuredriven innovation will have a large economic, spatial and environmental impact on China; it is also likely to transform entire regions throughout Asia, Africa and Europe. In pursuing it, the Chinese government seeks to meaningfully combine a strong national interest in infrastructural and economic development with an equally strong national interest in environmental sustainability. This chapter explores how it might meet both goals. How do the initiative's many projects intersect with local interests and needs in China? Will these investments carry out the proclaimed desire of the Chinese government for environmentally sustainable development? This chapter examines these questions by looking at how various governmental players are translating these investments and proposals into spatial plans. It focuses on port city regions, using the Dalian region in Northeast China, one of the OBOR Initiative hubs, as an example. Port regions are key spatial components in the OBOR Initiative: as infrastructural hubs and as centres for trade and innovation, as sites of national oil storage or as hubs for the development of new maritime technology. As places where the industrial production and long-distance infrastructure of OBOR encounters densely populated areas, they are also particularly at risk from climate change, including rising sea levels. Thus, the OBOR Initiative's goals of economic improvement and environmental sustainability may well collide.
\end{abstract}

Keywords: economic, environment, Dalian, one belt and one road, planning, port cluster, responsible.

\section{INTRODUCTION}

Since announcing the OBOR Initiative in late 2013, the Chinese government has promised to invest some 1 trillion dollars in massive land-based infrastructure (roads, railways, power plants and pipelines) along the historic Silk Route, and in port and maritime planning on the south side of the country, the so-called Maritime Silk Road. It will soon invest in the economic belt of the Northern Ice Sea Route as it opens up due to global warming [1]. This enormous investment is likely to transform cities and landscapes in Asia, the Middle East and parts of the European Union. Ports, port cities and regions of neighbouring areas - specifically the biggest ports with the most extensive infrastructures in China, including Shanghai, Guangzhou, Tianjin, Dalian and Haikou - are key economic and spatial nodes in the OBOR Initiative. These port cities are land- and sea-based hubs for commodities headed to international destinations. They are also hubs for production and transportation of energy and new maritime technologies, often hosting extensive industries (including many petroleum-based ones).

Current Chinese national economic plans and spatial strategies have two objectives: carrying out national demands for economic development and ecological sustainability as well as constraining what they frame as unhealthy autonomous local competition. Economic development and ecological sustainability can be opposing objectives. Port industries are often already big polluters. Located on lowlands, port cities and their coastal regions are particularly at risk of water-related environmental catastrophes [2,3]. The OBOR Initiative promises to further accelerate urbanization and industrialization, squeezing commerce, people and 
infrastructure into the already fragile ecosystem of the Chinese coastline. The dangers of this development have become evident in recent environmental disasters in port cities, including the 2015 explosions in Tianjin Port region and a recent oil spill in East China Sea in January 2018 [4]. Direct economic losses from marine disasters have totalled more than 32.8 billion U.S. dollars since 2010 [5].

This article explores how the OBOR Initiative aims to balance development and sustainability through spatial plans at diverse territorial scales - from provincial to municipal or port area. Subsequently, it examines how the national government has coordinated provincial governments, local municipalities and various industrial stakeholders to create regional synergetic development and spatial strategies to realize the OBOR. It studies how and to what degree the various institutions have implemented the spatial strategies. It specifically focuses on communication between the government, industrial representors and the general public to assess the degree of transparency in planning.

The objective of balancing economic with ecological sustainability is new to the OBOR Initiative, but the respective strategies are based on previous economic policies or concepts of environmental sustainability. Old and new plans and strategies have already shaped the spatial structure of ports, port cities and their neighbouring areas across the country. The OBOR Initiative, the Thirteenth-Five Year plan of 2016 and the programs of free trade zone (FTZ) since 2013, which ease economic regulations on industrial and commercial activities, including foreign ones, have inherited concepts of economic development and ecological sustainability from previous national strategies, such as the Plan for Revitalizing the 'Old Industrial Bases in Northeast China' issued by the State Council in 2006. They also inherited the principle of environmental protection from The State Council's Decision on Implementing the Scientific Outlook on Development and Strengthening Environmental Protection issued in 2005.

The article contends that the OBOR Initiative imagines and establishes a new spatial scale of the port cluster to implement its policy. The port cluster, conceived here both physically and analytically, consists a port, its city, the FTZ and their neighbouring area. It is first a regional space that supports port activities and comprises port facilities, maritime-related administrative offices and research institutions, logistics centres and infrastructural links of roads, rail and airports. In the absence of a single administrative unit in charge of this physical space, it is governed by various provincial, municipal and port institutions with often different interests and powers; in effect, it is a conceptual space. The Dalian Port Cluster, which includes the port and city of Dalian, the Liaoning FTZ and three neighbouring of Liaoning, Jilin and Heilongjiang, is the case study of the chapter (See Fig. 1). They are important spatial nodes in both the Economic Belt and Economic Road. Chosen by the central government to host the OBOR Initiative's activities, they have gotten national policy support and large investments from the central government.

\section{OBOR AND PORT CLUSTER}

Scholars have started to point out the effect of constructing the OBOR on the built environment - including Troy Sternberg, a specialist on the interaction of natural hazards with societies and the environment in the Gobi area in China - in order to create awareness of the unprecedented future transformation of the region's built environment in Central Asia [6]. Numerous scholars have studied the environmental advantages and risks of the OBOR Initiative's spatial projects in various border areas, including China-Russia [7], China-EU [8] and China-Iran [9]. Some have started to notice changes in port infrastructure and facilities; Orestis Schinas, professor of shipping and shipping finance at the Hamburg School of Business Administration, argues that the OBOR Initiative has influenced existing services 


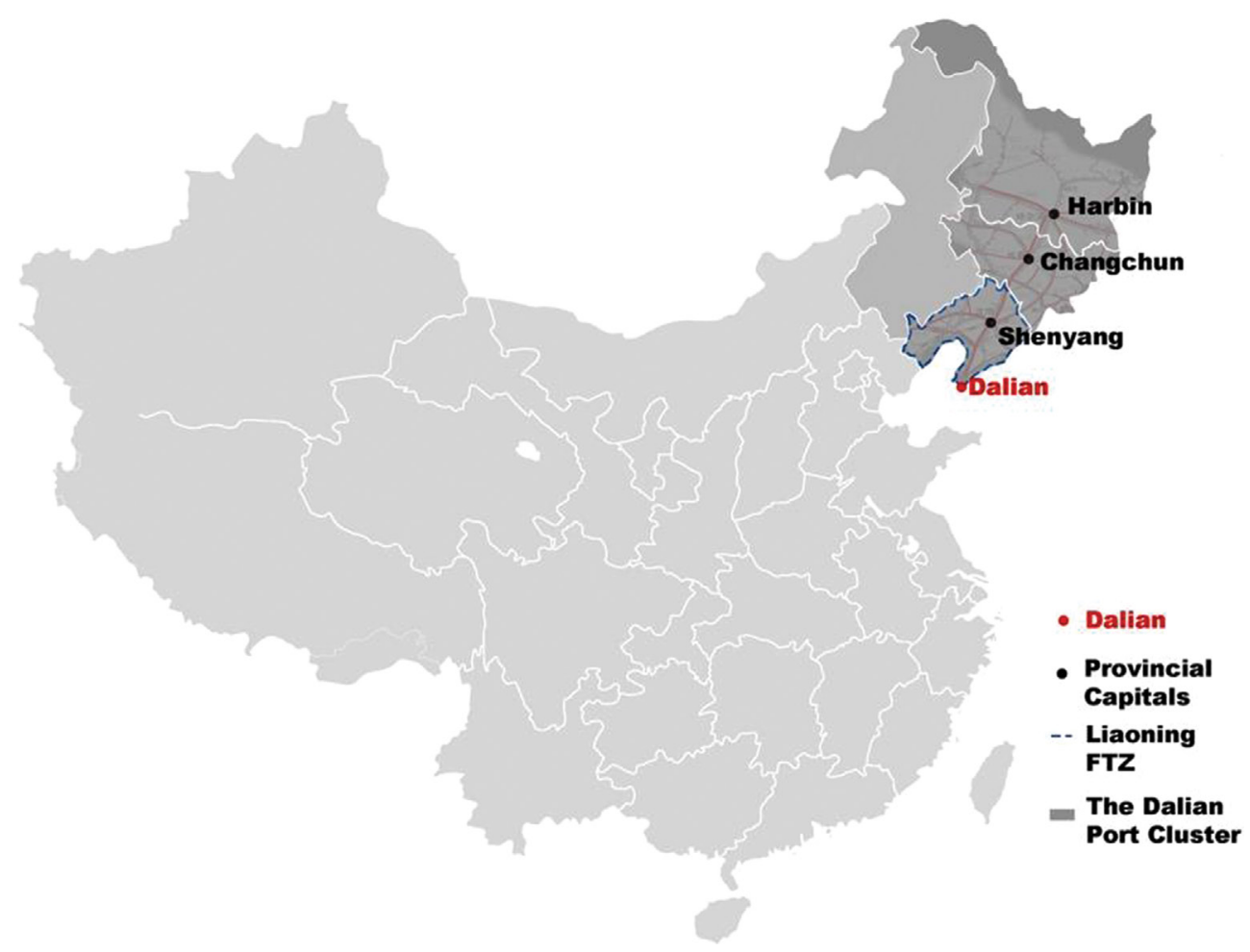

Figure 1: Schematic of the Dalian Port Cluster (Source: Penglin Zhu). The author made this schematic in April 2018.

and caused the re-routing of commodity flows [10]. Ports and port cities are priorities of the OBOR Initiative, and Prem Chhetri, professor of geo-logistic from University of Melbourne, and Paul Tae-Woo Lee, professor of marine economic from Zhejiang University, argue for studying these sites as cluster-led global port logistics to understand how these logistic networks have been strategically aligned in Asia by the OBOR Initiative and they also need to be understood functionally as global trading hubs and transport corridors [11]and , moreover, as focal points for socio-economic-political which drive the economic growth and spatial development in the context of the OBOR Initiative [12].

Official planning coordinates the enormous spatial projects of the OBOR Initiative. Scholars have recognized its role in promoting economic, technological, political and social innovation in light of the Initiative. But there is a lack of conversation about planning the world's largest port infrastructure and its effect on the environment. This chapter addresses this significant lacuna in this conversation. It highlights the importance of regional scale planning of the port, the port city and neighbouring areas for achieving the economic and environmental goals of the OBOR Initiative. It looks beyond the individual port, or a group of neighbouring area ports, to consider the relationship of the port to its vast hinterlands.

The OBOR project focuses on developing a number of regions with strong economies, wide-ranging trade relations, long histories and distinctive governance structures. Such developments require an appropriate conceptual and analytical framework. We argue that the Chinese practices are working at the level of what we propose is a port cluster. While this 
term is not mentioned in the Chinese texts, its conceptualization is necessary to understand the various actors and spaces involved and needed for and affected by the function of the port and the transformation of the sea at a regional level. Considering a larger region as the site in which to assess, guide and plan port city processes can help politicians, institutions and planners rethink competitiveness and synergy among cities as they consider sharing innovative information. It is especially important to understand what actors are involved at what spatial scale and what tools they have available.

Our definition of the port cluster enriches the common use of the port cluster, which describes a group of neighbouring ports in competitions. For example, Peter. W. de. Langen, a specialist in port logistics, argues that ports can be analysed as a group constituted by economic activities related to shipping routines; however, he has not studied the importance of the neighbouring area to the development of the port and port city [13]. In our usage, a port cluster includes the port, port cities and hinterland based on geographical distributions of an inland port in China, such as the division of three Chinese port clusters: the Northeast cluster, exclusively invested by the port of Dalian, the Central and West cluster led by the port of Tianjin and the Southeast cluster cooperating with the ports of Ningbo and Xiamen by maritime logistics expert Jason Monios from Edinburgh Napier University [14].

The chapter argues that the port cluster is the appropriate spatial concept for studying the spatial development of the port and city of Dalian and the neighbouring areas as sites of the OBOR Initiative. It can illuminate how the OBOR Initiative is re-branding the ports and their hinterlands as regions labelled with balancing the economic development and ecological sustainability. Scholars have used this concept of branding cities to study the arrangement of global cities [15], urban regeneration [16], spatial strategies of significant events [17] and urban governance in China [18]. The idea of the regional port cluster enriches the research on city branding in China which focuses on service and innovation-oriented cities, such as Pearl River Delta Area [19] and Jing-Jin-Ji Area [20], while rarely discussing the outdated resourcebased and heavy industry-based cities, including the ports and hinterlands in the three Northeastern provinces of Liaoning, Jilin and Heilongjiang. Furthermore, it is important to study the environmental planning of the OBOR Initiative and explore whether these plans are responsible and sustainable. For example, Martin de Jong, a Dutch specialist in urban and infrastructure development in China, uses the city branding concept to study the ecological modernization of various city groups in North-eastern China [21,22]. Wim Ravesteijn who has used examined the sustainability and responsibility of the port development projects in Dalian and Nansha Port $[23,24]$, but not to analyze spatial plans in the regional scale.

\section{PLANNING IN THE DALIAN PORT REGION: TOWARDS A BALANCE OF ECONOMIC DEVELOPMENT AND ECOLOGICAL SUSTAINABILITY?}

The OBOR Initiative has extensively addressed the concern for ecological sustainability. Together with the Ministry of Foreign Affairs, the National Development and Reform Commission and the Ministry of Commerce, the Ministry of Ecology and Environment issued the Guidance on promoting the construction of the green 'Belt and Road' in April 2017 and the Belt and Road Ecological and Environmental Cooperation Plan in May 2017, emphasising the national concern for ecological sustainability in the OBOR's projects. The Outline of the 13th Five-Year Plan for the National Economic and Social Development of the People's Republic of China (Thirteenth-Five Year Plan), issued in 2016, highlights ecological sustainability in one chapter, 'Moving faster to optimize the ecology and environment' as guidance for the local economic plans. 
But the national government's practice to balance economic development with regional ecological sustainability, so far, has had limited success in the context of the OBOR Initiative. For example, the Chinese Territory Development Plan (主体功能区规划) and the Chinese Marine Development Plan issued by the State Council in 2011 and 2015 respectively, have categorized four types of territories to develop: 'development zones to be optimized', 'key development zones', 'limited development zone' and 'prohibited development zones'. These plans do not explore how to balance preservation with the coastline petroleum industry, an economic pillar of Chinese port cities such as Qingdao and Dalian. Meanwhile, developing environment production industry, which is part of the ecological sustainability strategies, has not repayed to the economic increase. According to Xiuyan Sun, a journalist at the People's Daily, the environmental protection industry is facing difficulties since the annual production value is less than $2 \%$ of the national GDP, and it is not a backbone industry.

To fully realize the economic and ecological goals of the OBOR Initiative, the Chinese government needs regional scale planning agents. The Chinese government has long understood the importance of regional planning. Mostly, these regional plans identified economic and technical strategies. Specifically, regional government entities have only briefly existed, such as between 1949 and 1953. The previous national economic plans have addressed regional scales, such as old industrial bases in the Northern China (since 2006), the Bohai Economic Rim (since 1992) and the Pearl Economic Delta (since 1994). The Vision for Maritime Cooperation under the Belt and Road Initiative, a 2017 document by the National Development and Reform Commission and the State Oceanic Administration's the Thirteenth Five-Year Plan, each mapped out an overall strategy for coordinated development of city groups of Northeast China and Central China. Effectively, these plans established a vision of a comprehensive regional plan that would protect regional marine environments and address climate change. To achieve these, it would promote international cooperation, particularly to develop the so-called blue carbon, a mechanism for using marine activities and marine organisms to absorb carbon dioxide from the atmosphere, fix it and store it in the ocean.

The national government is planning at a regional scale in what we call the Dalian Port Cluster in Northeast China. The port and city of Dalian and the Liaoning FTZ are major parts of the Dalian Port Cluster, while the Jinlin and Heilongjiang Provinces are regional hinterlands in the cluster. Northeast China serves as an extension of the new Maritime Silk Route that connects the Middle East, East Asia and Africa. Liaoning Province serves as the starting point of the OBOR infrastructure, and Jilin and Heilong Provinces are important nodes on the Belt, whose massive markets are attractive to international businesses. Revitalizing the Industrial Bases in Northeast China issued by the National Development and Reforming Commission in 2017 presents the economic connection between the Liaoning Province (orange) and Jilin and Heilongjiang Provinces (green), showing the importance of the Liaoning province, specifically, the strategical position of the port of Dalian as the portal to the Northeast China. This plan proposes an infrastructural and developmental axis connecting the north-eastern cities, including Harbin (capital of Heilongjiang Province), Changchun (capital of Jilin Province), Shenyang and Dalian. Within this axis (the purple double-headed arrow in Fig. 2), regional infrastructure links Dalian Port to the river port in Harbin, a strategic location for energy transportation and storage in the northeast, and further on to the Russian Ports of Khabarovsk, Blagoveshchensk and Nikolayevsk [26]. These proposed infrastructural networks are also part of Medium- and Long-Term Plans for the National Gas Pipeline Network (中长期油气管网规划), issued by the National Development and Reform Commission and National Energy Administration in 2017, which proposes to construct storage for liquefied 


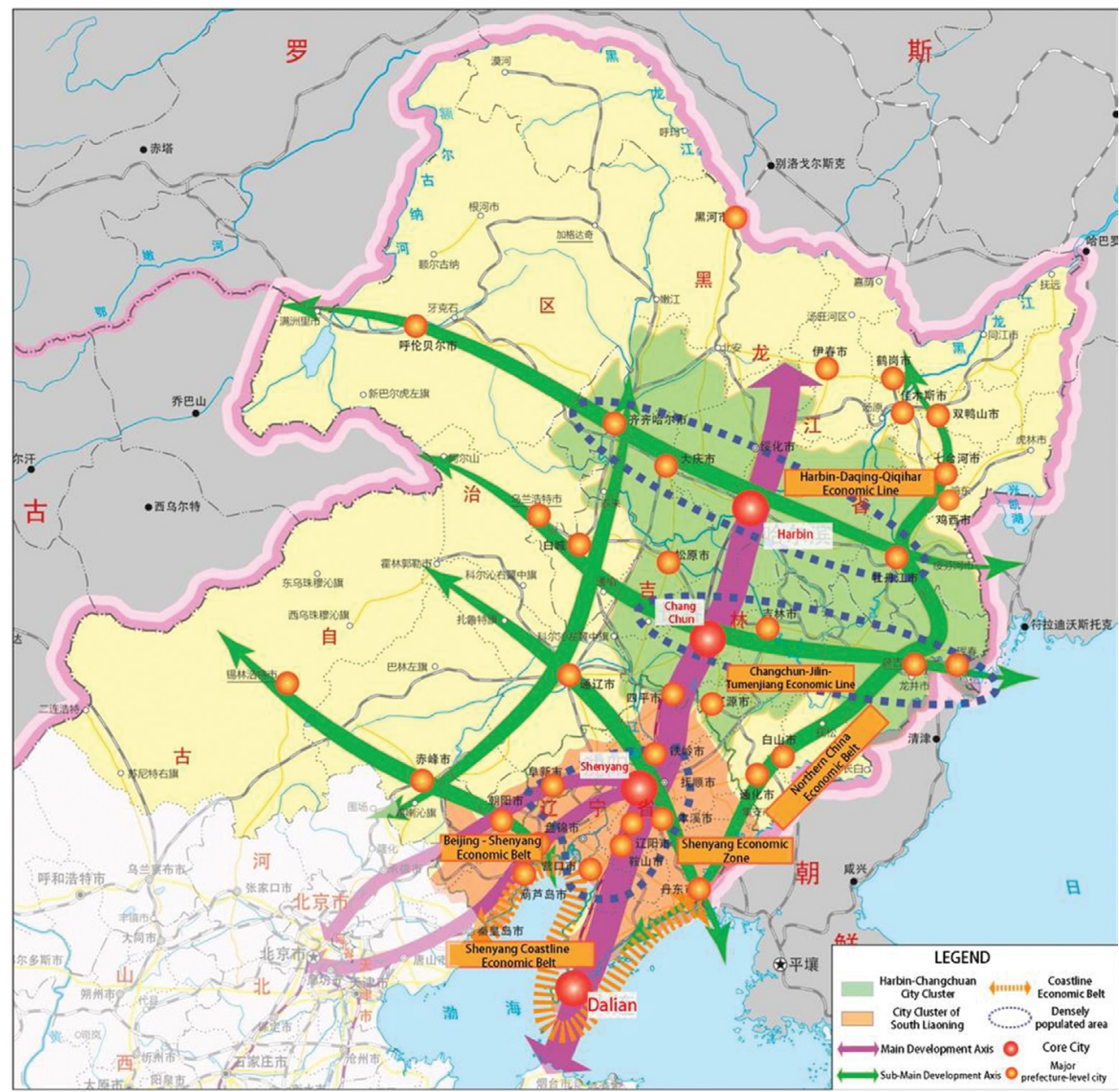

Figure 2: Thirteenth-Five Year Plan for Revitalizing the Old Schematic Plan of the cities and region identified in the Thirteenth-Five Year Plan for Revitalizing the Old Industrial Bases in the Northeast China, 十三五东北地区振兴计划 [25].

natural gas (LNG), reconstruct and extend the oil port and develop a new complementary pipeline network connecting offshore oil and gas platform to the hinterland.

Despite the national government's focus on planning at the regional scale here, there are no regional governmental institutions administrating the Dalian Port Cluster. Yet to actually build anything, the OBOR Initiative requires the support and synergy of various provincial and local governments, companies, nationally funded think tanks and academies, petroleum companies active in the ports and other industrial companies. In particular, port development requires investment into the landside infrastructure for distribution on a regional scale [27]. The development of a smooth and efficient transportation route here will rely on strong support from various provincial and municipal governments in the region, who are in charge of improving port infrastructure, strengthening port service and developing maritime logistics. The national government, provincial governments and local municipalities need to create 
synergies among several initiatives, the development of the port and the creation of a special economic area that facilitates (foreign) trade and regional-scale infrastructural planning.

The absence of regional governmental institutions makes it difficult for any regional synergy to create. Provincial and local governments are not always in agreement with the OBOR's overarching goals, and they tend to ignore parts of the national plans to pursue their own interests. Some try to create plans that realize national strategies while also furthering local goals, while others are primarily keen to capture part of the enormous national investment for local or other interests. Though most of the provincial plans thus far have focused on developing new green environmental protection technology to meet both economic and ecological objectives, the local plan, such as 2017 Revised Comprehensive Urban Plan of Dalian (2001-2020), mainly focuses on economic development and only mentions ecological sustainability in the program description of the transportation infrastructure.

Even when the various administrative levels mention overarching goals, the provincial government of Liaoning has not addressed how to coordinate its spatial plan for OBOR with those of Jilin Province and Heilongjiang Province, and neither of those provinces have proposed any communication with the others in their Thirteen five-year plans. Inter-province (or inter-municipal) communication channels and transparent procedures are missing, and processes to present the planning progress to the general public are absent.

Support for the implementation of the OBOR plan also needs to come from other stakeholders, such as the state-owned Dalian Port Company, but again it is unclear how they will balance economic and environmental goals and how they will translate these into spatial plans. The Dalian Port Company issued a Plan Towards the Green Ecological Port for 2015 2020 in 2014. It includes numerous environmental friendly concepts such as low carbon, environmentally friendly loading and unloading transportation equipment, solar energy for cleaning facilities, green building technologies, increasing green land in the port and new oil spill emergency and prevention systems. It is not yet clear whether and how these will play out in port construction or if the company will make other changes in response to the OBOR plan.

The major obstacle to achieving the OBOR's goals in Dalian Port Cluster is the un-transparency in planning progress and unsuccessful local supervision. Without transparency, whether and to what degree the governments have executed their promises through spatial plans are unknown. Therefore, no refinement can be adjusted to improve the practice. For instance, the Dalian Port Company Limited has claimed to use the newest protection system for the oil tanks since 2016, but several fires have broken out there, the most recent in August 2017 [28]. The port company of Dalian has not explained to society to what degree it can complete its promise. Information on other shortcomings is similarly missing. For example, according to a report from the Third Environmental Protection Inspectorate from the central government [29], the Dalian Port Company had illegally reclaimed 585 hectares of land from the water during the construction of the Taiping Bay Port Area. The inspectorate from the national government are touring domestically and can only defend the national interests rhetorically since it is not a law enforcement authority. The reason why the local supervision agency has ignored these actions of the Dalian Port Company has not been reported to the society.

Truly effective communication guarantees all parties that goals are achieved, that national and local interests are aligned and that planning is handled efficiently. It includes options for public engagement and public debate on policy, with the real possibility that officials will change the policy in response to public comment. Chinese institutions have addressed the need to establish a communication platform. The national 2007 Urban and Rural Planning 
Act designed a way for people to communicate, but will not be permanent or convenient tool for the general public for long term. The current Chinese planning system offers some channels through which the general public can send in comments or complaints on urban plans, including petitioning, but people have only briefly used this tool and does not obligate officials to respond. For example, the Dalian Port Company posted the first and second versions of the Environmental Impact Assessment of the Dalian Port Taipingwan Area Master plan on its website in 2017 for 10 days, allowing readers to comment only via telephone or email or by going in person to the Dalian Port Company offices, not online. Whether the planners responded to people or modified their plans, thus far, has not been announced in social media. A practice of negotiation or debate is currently not fully established in China. Transparent and straight communication among the governments, various stakeholders and the general public is needed to realize the overall goal of balancing economic and environmental objectives.

In short, the official stakeholders who execute national strategies and translate them into spatial plans have only partially adopted the national government's environmental and economic goals. How can the Chinese national government, provincial governments and the local municipality improve spatial planning and implementation and achieve their national goals in the Dalian Port Cluster? What are barriers that they need to overcome?

\section{CONCLUSION}

Examining the spatial impact of the OBOR Initiative, the article first posited the concept of the port cluster as a space in which to assess the implementation of the dual goals of the OBOR Initiative: economic development and ecological sustainability. It argues that the port cluster is the appropriate planning scale for national spatial strategies of the OBOR Initiative to coordinate economic development and ecological sustainability and that the urban scholars, port logistic specialists, environmental and ecological experts etc. need to identify and conceptualize it. As is clear from the Dalian case, collaboration in the port cluster needs to be improved to achieve the OBOR's two objectives.

Second, the chapter studied regional scale planning in the Dalian Port Cluster, exploring barriers to planning and implementing change. Though the national government has formed the Dalian Port Cluster from various national economic plans and spatial strategies, the untransparency and imbalance of economic development and ecological sustainability, the absence of a horizontal dialogue among the involved provinces and the absence of a vertical channel of communication between governments and the public all hinder the realization of the goals of the OBOR Initiative.

Such shortcomings in the planning and executing of the OBOR Initiative at the regional port cluster level may be due to the relatively short history of the OBOR Initiative. Others are more systemic. Traditional top-down Chinese planning practices can be advantageous in realizing such a huge project, but also hinder transparent and open communication with governments at all scales and the general public.

The Chinese government, provincial governments and other stakeholders involved in the OBOR Initiative have been learning to avoid any problems in planning, executing and supervision to better achieve the goals of the OBOR initiative. New concepts, methodologies and tools can then further their work. This paper is a contribution to point out the problems and disadvantages in the planning and process.

Going forward, understanding how different Chinese governmental institutions translate the OBOR Initiative into policies and plans within China will allow us to assess the role of 
local institutions and citizens in this continental scale transformation; it will also help us understand the planned expansion of the New Silk Road to ports and cities beyond China, with political and economic systems being often very different from those in China. The plan views the port of Hamburg, for example, as one of the main hubs for the New Silk Road. This North German port is already Europe's leading seaport for trade with China; among other dynamics, the high level of rail traffic (to transport containers) is possibly harming the environment. Other European port cities, including Rotterdam, Antwerp and Piraeus, are also already experiencing the impact of Chinese policy. For example, the nationally owned China Ocean Shipping (Group) Company has invested nearly half a billion euros in the port of Piraeus, making it the largest owner of the port. The OBOR Initiative will extend Chinese influence beyond the port to reshape neighbouring port cities and their hinterlands. As it figures out how to balance economic and environmental concerns at home, perhaps it can also learn to extend that balance abroad.

To conclude, the concept of port cluster is a prominent tool to study the planning process of the OBOR Initiative. The OBOR Initiative is still young and its implementers are definitely in the midst of a learning process. Further research on the methodology, which can help China assure that regional actors execute spatial plans in line with local needs and interests at the same time as they pursue both economic and environmental sustainability wherever they build, is required.

\section{REFERENCES}

[1] Huang, Y. \& Perlez, J., Behind China's \$1 Trillion Plan to Shake up the Economic Order, The New York Times, 13 May 2017.

[2] Hein, C., Port cities and urban waterfronts: How localized planning ignores water as a connector. Wiley Interdisciplinary Reviews: Water, 3(3), pp. 419-38, 2016.

[3] Hein, C., Oil spaces: The global petroleumscape in the Rotterdam/The Hague area. Journal of Urban History, 44(5), pp. 887-929, 2018.

[4] Mullany, G., Huge Oil Spill Spreads in East China Sea, Stirring Environmental Fears. The New York Times, 15 January 2018.

[5] Xinhua Net, China Reveals Risk Map of Marine Disasters, available at http://www. xinhuanet.com/english/2018-05/12/c_137174555.htm.

[6] Sternberg, T., Ahearn. A. \& McConnell. F., Central Asian 'Characteristics' on China's New Silk Road: The role of landscape and the politics of infrastructure. Land, 6(3), pp. 55-73, 2017.

[7] Tracy, E. F., Shvarts, E., Simonov, E. \& Babenko, M., China's new Eurasian ambitions: The environmental risks of the Silk Road Economic Belt. Eurasian Geography and Economics, 58(1), pp. 56-88, 2017.

[8] Fardella, E. \& Prodi, G., The Belt and Road Initiative Impact on Europe: An Italian perspective. China \& World Economy, 25(5), pp. 125-138, 2017. Doi: 10.1111/cwe. 12217.

[9] Shariatinia, M. \& Azizi, H., Iran-China cooperation in the Silk Road Economic Belt: From strategic understanding to operational understanding. China and World Economy, 25(5), pp. 46-61, 2017. Doi: 10.1111/Cwe.12213.

[10] Schinas, O. \& Westarp, A.G., Assessing the impact of the maritime Silk Road. Journal of Ocean Engineering and Science, 2(3), pp. 186-19, 2017. Doi: 10.1016/j. joes.207.08.002. 
[11] Chhetri, P., Nkhoma, M., Peszynski, K., Chhetri, A. \& Lee, P. T.-W., Global logistics city concept: A cluster-led strategy under the Belt and Road Initiative. Maritime Policy \& Management, 45(3), pp. 319-335, 2017. Doi: 10.1080/03088839.2017.1400700.

[12] Lee, P. T.-W., Hu, Z.-H., Lee, S.-J., Choi, K.-S. and Shin, S.-H., Research trends and agenda on the Belt and Road (B\&R) Initiative with a focus on maritime transport. Maritime Policy \& Management, 45(3), pp. 282-300, 2018. Doi: 10.1080/03088839.2017.1400189.

[13] de Langen, P. W. \& Visser, E.-J., Collective action regimes in seaport clusters: The case of the Lower Mississippi port cluster. Journal of Transport Geography, 13(2), pp. 173-186, 2005. Doi: 10.1016/j.jtrangeo.2004.04.010.

[14] Monios, J. \& Wang, Y., Spatial and institutional characteristics of inland port development in China. Geo Journal, 78(5), pp. 897-913, 2013. Doi: 10.1007/s10708-0139473-2.

[15] Wu, F. \& Phelps, N. A., From Suburbia to Post-Suburbia in China? Aspects of the transformation of the Beijing and Shanghai global city regions. Built Environment, 34(4), pp. 464-481, 2008. Doi: 10.2148/benv.34.4.464.

[16] Lin, Y., Urban regeneration in China: Policy, development, and issues. Local Economy: The Journal of the Local Economy Policy Unit, 26(5), pp. 337-347, 2011. Doi: 10.1177/0269094211409117

[17] Zhang, L. \& Zhao, S.X., City Branding and the Olympic effect: A case study of Beijing. Cities, 26(5), pp. 245-254, 2009. Doi: 10.1016/j.cities.2009.05.002.

[18] Ye, L. \& Björner, E., Linking city branding to multi-level urban governance in Chinese mega-Cities: A case study of Guangzhou. Cities, 80, pp. 29-37. Doi: 10.1016/j.cities.2017.10.018.

[19] Bie, J., de Jong, M. \& Derudder, B., Greater Pearl River Delta: Historical evolution towards a global city-region. Journal of Urban Technology, 22(2), pp. 103-123, 2015. Doi: 10.1080/10630732.2014.971575.

[20] Xiong, L., Yu, C., de Jong, W. M., Wang, F. \& Cheng, B., Economic transformation in the Beijing-Tianjin-Hebei Region: Is it undergoing the environmental Kuznets curve? Sustainability, 9(5), pp. 869-869, 2017. Doi: 10.3390/su9050869.

[21] de Jong, M., Chen, Y., Joss, S., Lu, H., Zhao, M., Yang, Q. \& Zhang, C., Explaining city branding practices in China's three mega-city regions: The role of ecological modernization. Journal of Cleaner Production, 179, pp. 527-543, 2018 Doi: 10.1016/j. jclepro.2018.01.098.

[22] Han, M., de Jong, M., Cui, Z., Xu, L., Lu, H. \& Sun, B., City Branding in China's northeastern region: How do cities reposition themselves when facing industrial decline and ecological modernization? Sustainability, 10(2), pp. 102-102, 2018. Doi: 10.3390/ su10010102.

[23] Ravesteijn, W., He, J. \& Chen, C., Responsible innovation and stakeholder management in infrastructures: The Nansha Port Railway Project. Ocean \& Coastal Management, 100, pp. 1-9, 2014. Doi: 10.1016/j.ocecoaman.2014.07.005

[24] Ravesteijn, W., Liu, Y. \& Yan, P., Responsible innovation in port development: The Rotterdam Maasvlakte 2 and the Dalian Dayao Bay Extension Projects. Water science and Technology : A Journal of the International Association on Water Pollution Research, 72(5), pp. 665-77, 2015. Doi: 10.2166/wst.2015.272.

[25] Source: National Development and Reform Commission] . available at http://www. ndrc.gov.cn/zcfb/zcfbghwb/201612/W020161219594214175674.pdf. 
[26] Xie, L., Yang, Z., Cai, J., Cheng, Z., Wen, T. \& Song, T., Harbin: A Rust belt city revival from its strategic position, Cities, 58, pp. 26-38, 2016. Doi: 10.1016/j.cities.2016.05.009.

[27] Pardali, A., Kounoupas, E. \& Lainos, I., Can clusters be bi-polar? Exploring the case of the Piraeus Port-Maritime cluster. Maritime Policy \& Management, 43(6), pp. 706719, 2016. Doi: 10.1080/03088839.2016.1169447.

[28] Sina Comprehensive; Petrochina (Dalian) Petrochemical Has Frequent Fires: It Is the Seventh Accident since 2010, 中石油大连石化火灾频发: 2010年至今已是第七次 事故; http://finance.sina.com.cn/chanjing/gsnews/2017-08-18/doc-ifykcypp8898450. shtml. (accessed 18 August 2017).

[29] Diao, F., Taipingwan Port (Dalian) Has Been Fined 10 Million for Illegal Reclamation, and Local Subsidies Are All Paid Back, 太平湾港区违法填海被罚千万当地又以补 贴全返, http://m.thepaper.cn/newsDetail_forward_1747484. (accessed 31 July 2017). 